\title{
A Novel Lectin with Antiproliferative and HIV-1 Reverse Transcriptase Inhibitory Activities from Dried Fruiting Bodies of the Monkey Head Mushroom Hericium erinaceum
}

\author{
Yanrui Li, ${ }^{1}$ Guoqing Zhang, ${ }^{1}$ Tzi Bun $\mathrm{Ng}^{2}$ and Hexiang Wang1 \\ ${ }^{1}$ State Key Laboratory for Agrobiotechnology, Department of Microbiology, China Agricultural University, Beijing 100193, China \\ ${ }^{2}$ School of Biomedical Sciences, Faculty of Medicine, The Chinese University of Hong Kong, Shatin, New Territories, Hong Kong \\ Correspondence should be addressed to Tzi Bun Ng, b021770@mailserv.cuhk.edu.hk and \\ Hexiang Wang, hxwang1957@gmail.com
}

Received 4 March 2010; Revised 14 April 2010; Accepted 14 April 2010

Academic Editor: Stavros J. Hamodrakas

Copyright (C) 2010 Yanrui Li et al. This is an open access article distributed under the Creative Commons Attribution License, which permits unrestricted use, distribution, and reproduction in any medium, provided the original work is properly cited.

\begin{abstract}
A lectin designated as Hericium erinaceum agglutinin (HEA) was isolated from dried fruiting bodies of the mushroom Hericium erinaceum with a chromatographic procedure which entailed DEAE-cellulose, CM-cellulose, Q-Sepharose, and FPLC Superdex 75. Its molecular mass was estimated to be $51 \mathrm{kDa}$ and its $\mathrm{N}$-terminal amino acid sequences was distinctly different from those of other isolated mushroom lectins. The hemagglutinating activity of HEA was inhibited at the minimum concentration of $12.5 \mathrm{mM}$ by inulin. The lectin was stable at $\mathrm{pH} 1.9-12.1$ and at temperatures up to $70^{\circ} \mathrm{C}$, but was inhibited by $\mathrm{Hg}^{2+}, \mathrm{Cu}^{2+}$, and $\mathrm{Fe}^{3+}$ ions. The lectin exhibited potent mitogenic activity toward mouse splenocytes, and demonstrated antiproliferative activity toward hepatoma (HepG2) and breast cancer (MCF7) cells with an $\mathrm{IC}_{50}$ of $56.1 \mu \mathrm{M}$ and $76.5 \mu \mathrm{M}$, respectively. It manifested HIV-1 reverse transcriptase inhibitory activity with an $\mathrm{IC}_{50}$ of $31.7 \mu \mathrm{M}$. The lectin exhibited potent mitogenic activity toward murine splenocytes but was devoid of antifungal activity.
\end{abstract}

\section{Introduction}

Lectins are proteins of nonimmune origin which are able to agglutinate cells through sugar-specific binding sites and precipitate polysaccharides and glycoconjugates. Lectins possess at least one non-catalytic domain, which binds reversibly to a specific mono- or oligo-saccharide. Lectins, proteins characterized by their ability to interact with carbohydrates, can be divided into different groups according to their sugar binding specificity [1]. Lectins are abundant in vegetables, fruits, beans and mushrooms [2-6]. Agaricus bisporus lectin (ABL) is well documented because it is the most popular edible mushroom in western countries [4, 5]. Other lectins have been found in higher mushrooms, Sclerotium rolfsii [7], Volvariella volvacea [8], Ganoderma capense [9], Tricholoma mongolicum, Pleurotus ostreatus, Agrocybe cylindracea [10-12], Schizophyllum commune [13], Armillaria luteo-virens [14], Agaricus blazei, Grifola frondosa, Pholiota aurivella, Hericium erinaceum, Ganoderma lucidum,
Pleurotus ostreatus, and Mycoleptodonoides aitchisonii [1521]. Mushroom lectins have different biological activities. Previous studies have demonstrated exploitable biological activities such as antitumor [11], immunomodulatory [8], HIV-1 reverse transcriptase inhibiting [22], cell growth regulating [12], macrophage and lymphocyte activating [23], antiproliferative activities [12], and so on.

Hericium erinaceum, also called monkey head mushroom, is a well known edible and medicinal mushroom in oriental countries. In Japan it is called yamabushitake, and in China it is called houtou which means monkey head [24]. In recent years, $H$. erinaceum has attracted a great deal of attention of owing to its antimicrobial [25], antitumor [26, 27], immunomodulatory [28], antioxidant [29], and cytotoxic activities [27]. Furthermore, it promoties the synthesis of neurogrowth factor [30-33].

A polysaccharide with antitumor activity [34], and a laccase [35] have been reported from $H$. erinaceum. From the fresh fruiting bodies of $H$. erinaceum, a sialic acid-binding 
lectin (HEL) with a blocked N-terminal and a molecular mass of approximately $54 \mathrm{kDa}$ has been isolated [17]. The cultures or extracts of $H$. erinaceum processed into tablets have been put into production on a large scale, mainly for curing gastric ulcer and chronic gastricism [36].

In the present study, we isolated and characterized a novel lectin from the dried fruiting bodies of H. erinaceum. It possessed a relatively high heat stability and $\mathrm{pH}$ stability, a unique amino acid $\mathrm{N}$-terminal amino acid sequence, potent mitogenic activity toward murine spleen cells, reverse transcriptase HIV-1 inhibiting activity and antipoliferative activity on tumor cells. In particular, this lectin is different from HEL in some aspects. Since H. erinaceum is used in traditional Chinese medicine, the results of the present study would provide a scientific basis for the medicinal use of this mushroom.

\section{Materials and Methods}

2.1. Purification Scheme. Dried fruiting bodies $(20 \mathrm{~g})$ of the H. erinaceum were homogenized in $150 \mathrm{mM} \mathrm{NaCl}(25 \mathrm{ml} / \mathrm{g})$ using a Waring blender and then soaked in $500 \mathrm{ml}$ of $150 \mathrm{mM} \mathrm{NaCl}$ for 12 hours. The slurry was then centrifuged at $8000 \times \mathrm{g}$ for 15 minutes. Afterward $\left(\mathrm{NH}_{4}\right)_{2} \mathrm{SO}_{4}$ was added into the supernatant to $80 \%$ saturation. The precipitate was collected by centrifugation $\left(8000 \times \mathrm{g}, 4^{\circ} \mathrm{C}, 15\right.$ minutes $)$, and dissolved in a small amount of distilled water and dialyzed until the final concentration of $10 \mathrm{mM}$ phosphate-buffered saline ( $\mathrm{pH}$ 7.0) was attained. The crude extract was then applied to a column of DEAE-cellulose column (Sigma, $1.0 \mathrm{~cm} \times 15 \mathrm{~cm}$ ) which had been previously equilibrated with $10 \mathrm{mM}$ phosphate-buffered saline ( $\mathrm{pH}$ 7.0). Following elution of the unadsorbed fraction D1 with the starting buffer, fractions D2 and D3 were obtained by eluting the column with $50 \mathrm{Mm} \mathrm{NaCl}$ and $300 \mathrm{mM} \mathrm{NaCl}$ in the phosphatebuffered saline respectively. The active fraction (D3) was applied to a CM-cellulose column (Sigma, $1.0 \mathrm{~cm} \times 15 \mathrm{~cm}$ ) in $10 \mathrm{mM} \mathrm{NH}_{4} \mathrm{OAc}$ buffer ( $\mathrm{pH}$ 5.1). After removal of the unadsorbed protein with the starting buffer, the column was eluted with $50 \mathrm{mM} \mathrm{NaCl}$ in the starting buffer to attain the active fraction C2. Subsequently it was further fractionated on an ion exchange chromatography Q-Sepharose column (Sigma, $0.5 \times 10 \mathrm{~cm}$ ). After the unadsorbed fraction (Q1) had been eluted in $10 \mathrm{mMNH}_{4} \mathrm{OAc}$ buffer ( $\mathrm{pH}$ 5.1), the adsorbed fractions were eluted with a linear gradient of $0-400 \mathrm{mM} \mathrm{NaCl}$ in the same buffer. The active peak (Q3) was subjected to final purification on a Superdex G-75 HR $10 / 30$ column by fast protein liquid chromatography using an AKTA Purifier (GE Healthcare, US) and was eluted with $10 \mathrm{mM}$ phosphate buffer ( $\mathrm{pH}$ 7.5) containing $150 \mathrm{mM} \mathrm{NaCl}$. Peak SU1 represented the purified lectin (HEA).

2.2. Determination of Molecular Mass and N-Terminal Sequence. The purified lectin was subjected to sodium dodecyl sulfate-polyacrylamide gel electrophoresis (SDSPAGE) for molecular mass determination following with the procedure of Laemmli and Favre (1973) [37]. Gel filtration on a performed Superdex 75 HR 10/30 column (GE
Healthcare, US), which had been calibrated with molecular mass markers, was also obtained for the molecular mass determination of the lectin. The N-terminal sequence of the lectin was obtained by using a Hewlett-Packard HP G1000A Edman degradation unit and an HP 1000 HPLC System [37].

2.3. Assay of Lectin (Hemagglutinating) Activity. In the assay for lectin (hemagglutinating) activity, a serial twofold delution of the lectin solution in microtiter U-plates $(50 \mu \mathrm{l})$ was mixed with $50 \mu \mathrm{l}$ of $2 \%$ suspension of rabbit red cells in phosphate-buffered saline $\left(\mathrm{pH} \mathrm{7.2)}\right.$ at $20^{\circ} \mathrm{C}$. The results were recorded after about 1 hour when the blank had fully sedimented. The hemagglutintion titer, defined as the reciprocal of the highest dilution of the samples exhibiting hemagglutination, was reckoned as one hemagglutination unit. Specific activity is the number of hemagglutination units per mg protein [11].

The hemagglutination inhibition tests to investigate inhibition of lectin-induced hemagglutination by various carbohydrates were executed in a way similar to the hemagglutination test. The carbohydrates examined comprised inulin, D-melibiose, D-fructose, L-arabinose, L-rhamnose, $\mathrm{D}$-xylose, L-sorbose, inositol, lactose, D-galactose, sorbose, $\mathrm{D}$-arabinose, adonitol, cellobiose, D-glucose, D-mannose, raffinose, turanose, sucrose, maltose, and dulcitol. Serial twofold dilutions of sugar samples were prepared in phosphate buffered saline. All of the dilutions were mixed with an equal volume $(25 \mu \mathrm{l})$ of a solution of the lectin with 32 hemagglutination units. The mixture was permitted to stand for 30 minutes at room temperature and then mixed with $50 \mu \mathrm{l}$ of a $2 \%$ rabbit erythrocyte suspension. The minimum concentration of the sugar in the final reaction mixture which completely inhibited 32 hemagglutination units of the lectin preparation was computed [11].

The effects of $\mathrm{NaOH}, \mathrm{HCl}$, metal chlorides, and temperature on hemagglutininating activity of the lectin were studied as previously described in $[11,12]$.

2.4. Assay of Antiproliferative Activity on Tumor Cell Lines. The tumor cell lines, human breast cancer (MCF7) and hepatoma (HepG2), were acquired from American Type Culture Collection (ATCC). They were kept in Dulbecco modified Eagl's medium (DMEM) containing 10\% fetal bovine serum (FBS), $100 \mathrm{mg} / \mathrm{L}$ streptomycin and $100 \mathrm{IU} / \mathrm{ml}$ penicillin at $37^{\circ} \mathrm{C}$ in a humidified atmosphere of $5 \% \mathrm{CO}_{2}$. Cells $\left(1 \times 10^{4}\right)$ in their exponential growth phase were seeded into each well of a 96-well culture plate (Nunc, Denmark). Incubation was carried out for 3 hours before addition of the lectin. Incubation was then continued for another 48 hours. Radioactive precursor, $1 \mu \mathrm{Ci}$, ([ ${ }^{3} \mathrm{H}$-methyl] thymidine, from GE Healthcare) was then added to each well and incubated for 6 hours. The cultures were then harvested by means of a cell harvester. The incorporated radioactivity was determined by liquid scintillation counting [44].

2.5. Assay for HIV-1 Reverse Transcriptase Inhibitoryactivity. The inhibitory activity towards human immunodeficiency 
TABLE 1: Summary of purification of HEA (from $20 \mathrm{~g}$ dried fruit bodies).

\begin{tabular}{|c|c|c|c|c|}
\hline $\begin{array}{c}\text { Chromatographic } \\
\text { fraction }\end{array}$ & $\begin{array}{c}\text { Yield } \\
(\mathrm{mg} / 20 \mathrm{~g})\end{array}$ & $\begin{array}{c}\text { Total } \\
\text { Hemagglutinating } \\
\text { Activity } \\
\mathrm{U} \times 10^{5}\end{array}$ & $\begin{array}{c}\text { Specific } \\
\text { hemagglutinating } \\
\text { Activity } \\
(\mathrm{U} / \mathrm{mg})\end{array}$ & $\begin{array}{c}\text { Recovery } \\
\text { hemagglutinating } \\
\text { Activity } \\
(\%)\end{array}$ \\
\hline Crude Extract & 11840 & 3.6 & 30.64 & 100 \\
\hline Ammonium & & & & \\
\hline $\begin{array}{c}\text { sulfate } \\
\text { precipitate }\end{array}$ & 989.6 & 5.12 & 517 & 8.358 \\
\hline D1 & 149.71 & - & - & - \\
\hline D2 & 67.5 & - & - & - \\
\hline D3 & 175.058 & 1.66 & 950 & 1.4 \\
\hline D4 & 759.75 & 1.6 & 2.1 & 6.4 \\
\hline $\mathrm{C} 1$ & 50.754 & - & - & - \\
\hline $\mathrm{C} 2$ & 27.516 & 0.544 & 1978 & 0.23 \\
\hline $\mathrm{C} 3$ & 45.528 & - & - & - \\
\hline $\mathrm{C} 4$ & 20.985 & - & - & - \\
\hline Q1 & 0.6044 & - & - & - \\
\hline Q2 & 8.3924 & - & - & - \\
\hline Q3 & 13.34 & 0.512 & 3838 & 0.11 \\
\hline SU1 & 10.35 & 0.5 & 4830 & 0.087 \\
\hline SU2 & 3.04 & - & - & - \\
\hline
\end{tabular}

The lectin-enriched fractions and the associated data are highlighted in boldface.

virus type 1 (HIV-1) reverse transcriptase (RT) was evaluated by using an enzyme-linked immunosorbent assay (ELISA) kit from Boehringer Mannheim (Germany). The assay makes use of the ability of reverse transcriptase to synthesize DNA, commencing from the template/primer hybrid poly $(\mathrm{A})$-oligo $(\mathrm{dT})_{15}$. The digoxigenin- and biotinlabeled nucleotides in an optimized ratio are incorporated into the DNA molecule synthesized by the RT. The detection and quantification of the synthesized DNA as a measure of RT activity follows sandwich ELISA protocol. A fixed amount (4-6 ng) of recombinant HIV-1 RT was used. The inhibitory activity of the lectin was expressed as percent inhibition as compared to a control without the protein [45].

2.6. Assay of Mitogenic Activity Toward Mouse Splenocytes. Four C57BL/6 mice (20-25 g) were sacrificed by cervical dislocation and the spleens were aseptically excised. Splenocytes were isolated by pressing the tissue through a sterilized 100mesh stainless steel sieve and respended to $5 \times 10^{6}$ cells $/ \mathrm{ml}$ in RPMI 1640 culture medium containing 10\% fetal bovine serum, 100 units penicillin $/ \mathrm{ml}$, and $100 \mu \mathrm{g}$ streptomycin $/ \mathrm{ml}$. The splenocytes $\left(7 \times 10^{5} \mathrm{cells} / 0.1 \mathrm{ml} /\right.$ well $)$ were seeded into a 96-well culture microplates and a serial dilution of the lectin in $100 \mu \mathrm{l}$ medium was added. Following incubation of the splenocytes at $37^{\circ} \mathrm{C}$ in a humidified atmosphere of $5 \%$ carbon dioxide in the presence or absence of the lectin for 24 hours, the cells in one well were pulsed with $10 \mu \mathrm{Ci}$ $\left[{ }^{3} \mathrm{H}\right.$-methyl] thymidine (specific activity $0.25 \mu \mathrm{Ci} / \mathrm{mmol}$, GE Healthcare) was added, and the splenocytes were incubated for another 6 hours under the same conditions, and then harvested onto a glass fiber filter using an automated cell harvester. The radioactivity was counted using a Beckman model LS 6000SC scintillation counter. The proliferative (mitogenic) response was expressed as mean counts per minute (cpm) [44]. All reported values are the means of triplicate samples.

2.7. Assay of Antifungal Activity. The assays were conducted as detailed by Wang and $\mathrm{Ng}$ [46]. The assay for inhibitory activity toward the fungi Fusarium oxysporum, Rhizoctonia cerealis, Rhizoctonia solani, and Sclerotinia sclerotiorum was carried out in $100 \mathrm{mM} \times 15 \mathrm{mM}$ petri dishes containing $10 \mathrm{ml}$ of potato dextrose agar (PDA). After formation of the mycelial colony, sterile blank paper disks $(0.625 \mathrm{~cm}$ in diameter) were deposited at a distance of $0.5 \mathrm{~cm}$ away from the circumference of the mycelial colony. An aliquot $(15 \mu \mathrm{l})$ of the lectin was added to a disk. The dishes were incubated at $25^{\circ} \mathrm{C}$ for 72 hours until mycelial growth had encircled the disks containing the control and had produced crescents of inhibition around disks containing samples with antifungal activity.

\section{Results and Discussion}

3.1. Isolation and Purification of HEA. Hemagglitinating activity in the fruiting body extract was adsorbed successively on DEAE-cellulose, CM-cellulose, and Q-Sepharose columns. Activity was located in peaks D3, C2, and Q3 (Figures 1(a), 1(b) and 1(c)). The purified fraction SU1 was obtained through gel filtration on a Superdex G-75 HR 10/30 column (Figure 1(d)). The yields and specific hemagglutinating activities of the various chromatographic 


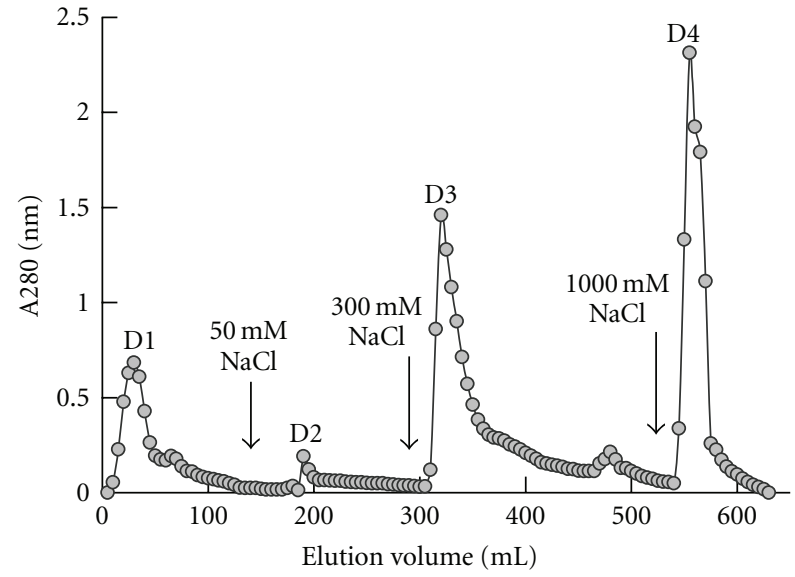

(a)

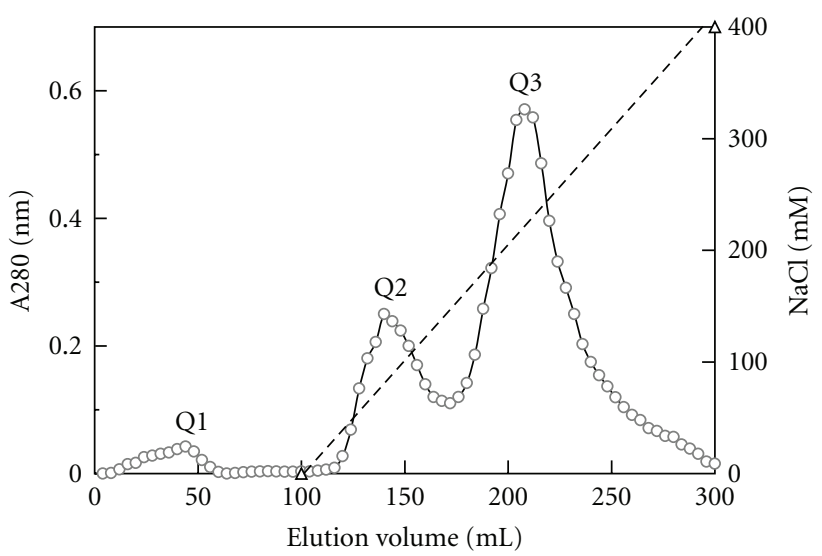

(c)

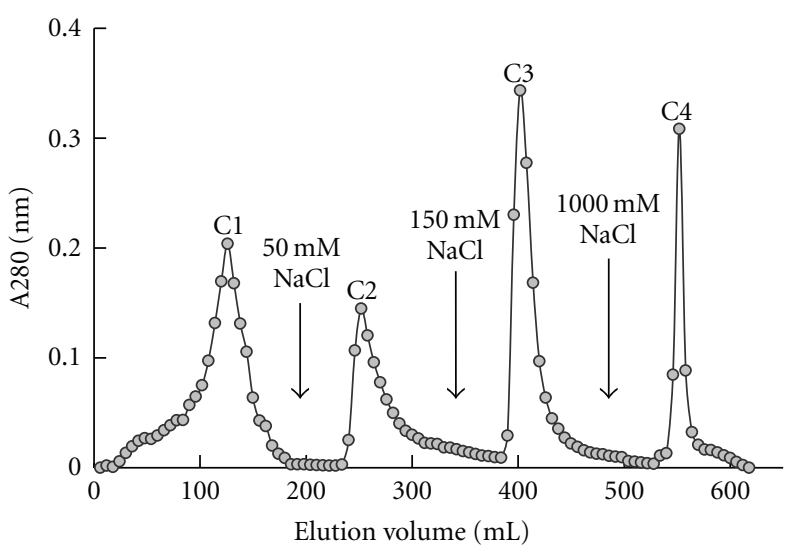

(b)

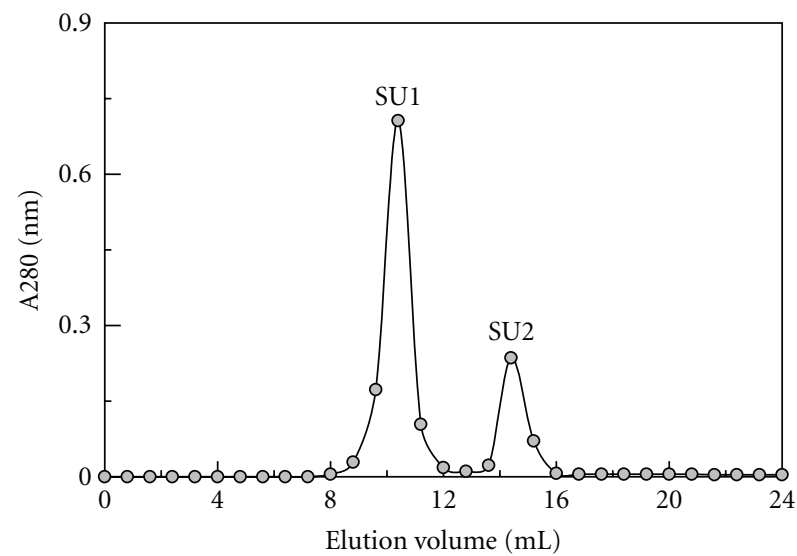

(d)

FIGURE 1: Elution profiles of HEA. (a) Anion exchange chromatography of protein derived from the $\left(\mathrm{NH}_{4}\right)_{2} \mathrm{SO}_{4}$ precipitate of crude extract of $H$. erinaceum fruiting bodies on a DEAE-cellulose column $(1.0 \mathrm{~cm} \times 20 \mathrm{~cm})$. which was equilibrated and eluted with $10 \mathrm{mM}$ phosphatebuffered ( $\mathrm{pH} 7.0$ ). Arrows indicate elution of the column stepwise with $50 \mathrm{mM}, 300 \mathrm{mM}$ and $1000 \mathrm{mM} \mathrm{NaCl}$ in the starting buffer. (b) Ion exchange chromatography of D3 on a CM-cellulose column $(2.0 \mathrm{~cm} \times 15 \mathrm{~cm})$. Arrows indicate elution of the column stepwise with $50 \mathrm{mM}$, $150 \mathrm{mM}$ and $1000 \mathrm{mM} \mathrm{NaCl} 10 \mathrm{mM} \mathrm{NH}_{4} \mathrm{OAc}$ buffer (pH 5.1). (c) Ion exchange chromatography of fraction C2 on a Q-Sepharose column $(1.0 \mathrm{~cm} \times 10 \mathrm{~cm})$. The slanting line across the chromatogram denotes a linear $\mathrm{NaCl}$ concentration $\left(0\right.$ to $400 \mathrm{mM}^{2}$ gradient in $10 \mathrm{mM} \mathrm{NH} 4 \mathrm{OAc}$ buffer (pH 5.1). (d) Gel filtration of fraction Q3 from Q-Sepharose column on a Superdex G-75 column, which was eluted with $10 \mathrm{mM}$ phosphate buffer ( $\mathrm{pH} 7.5$ ) containing $150 \mathrm{mM} \mathrm{NaCl}$. The flow rate was $0.4 \mathrm{ml} / \mathrm{min}$.

fractions are given in Table 1. The purified lectin appeared as a single band with a molecular mass of $51 \mathrm{kDa}$ in SDS/PAGE (Figure 2) and a peak (SU1) with a molecular mass of $51 \mathrm{kDa}$ in FPLC gel filtration. The N-terminal sequence of the HEA was AFGQLSFANLAAADF, different from the other mushroom lectins shown in Table 2. A blast search revealed that there was only slight resemblance to other previously reported lectins.

HEA isolated in the present investigation differed from lectins purified from other mushrooms. HEA was adsorbed on DEAE-cellulose and CM-cellulose, and eluted with $300 \mathrm{mM} \mathrm{NaCl}$ and $50 \mathrm{mM} \mathrm{NaCl}$, respectively. It was deadsorbed from Q-Sepharose column with a linear $\mathrm{NaCl}$ concentration gradient (0 to $400 \mathrm{mM}$ ). Compared with HEA, another $H$. erinaceum lectin HEL was adsorbed DEAEToyopearl column and Mono-S column. HEL could be also purified from the ammonium sulfate precipitate by affinity chromatography on BSM- or asialo-BSM-Toyopearl. But, recovery of the activity by affinity chromatography was much lower than that of this study procedure $(10 \%$ and $8.7 \%$, resp.) [17]. What is more, in each step a substantial amount of protein devoid of hemagglutininating activity was eliminated, indicating that the procedure was an effective one. Different from HEL which is composed of two different subunits with a molecular mass of $15 \mathrm{kDa}$ and $16 \mathrm{kDa}$, HEA is monomeric with a molecular mass approximating $51 \mathrm{kDa}$. HEA displayed an N-terminal sequence with little resemblance to some of the published mushroom lectins, such as those from Agrocybe aegerita, Laccaria bicolor, Coprinopsis cinerea, Thermophilanous ganoderma, Agaricus bisporus, Pleurotus cornucopiae, Flammulina velutipes, and Grifola frondosa (shown in Table 2) [9, 18, 38-43]. 
TABLE 2: N-terminal sequence of HEA with other mushroom lectins.

\begin{tabular}{|c|c|c|}
\hline Species & $\mathrm{N}$-terminal sequence & Reference number \\
\hline Hericium erinaceum & AFGQLSFANLAAADF & this study \\
\hline Laccaria bicolor & SHLYGDGVAL & {$[38]$} \\
\hline Coprinopsis cinerea & IPLEGTFG $\underline{\mathrm{D} R}$ & [39] \\
\hline Thermophilanous ganoderma & VNDYEANYGADDD & [9] \\
\hline Pleurotus cornucopiae & SDSTWTFAML & {$[40]$} \\
\hline Agaricus bisporus & MGGSGTSGSL & {$[41]$} \\
\hline Agrocybe aegerita & NISAGTSVDL $\underline{\underline{L}}$ & [42] \\
\hline Flammulina velutipes & TSLTFQLAYL & [43] \\
\hline Grifola frondosa & NWPAEMMIDLKHPIVEMR & {$[18]$} \\
\hline
\end{tabular}

Identical amino acid residues are highlighted in boldface and underscored.

TABLE 3: Effect of temperature on hemagglutinating activity of HEA.

\begin{tabular}{llllllllll}
\hline Temperature $\left({ }^{\circ} \mathrm{C}\right)$ & 20 & 30 & 40 & 50 & 60 & 70 & 80 & 90 & 100 \\
$\begin{array}{l}\text { Hemagglutinating activity } \\
(\mathrm{U})\end{array}$ & 64 & 64 & 64 & 64 & 64 & 64 & 32 & 0 & 0 \\
\hline
\end{tabular}

Initial hemagglutinating activity of HEA solution was 64 hemagglutinating units.

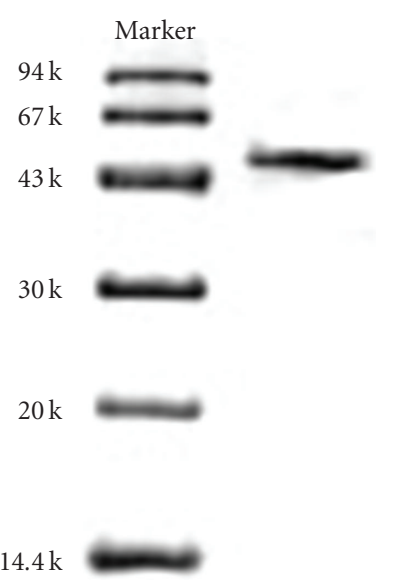

FIgURE 2: SDS-PAGE of fraction SU1 (purified HEA in the right line) from Superdex 75 column. Molecular mass markers (left lane) are: phosphorylase b $(94 \mathrm{kDa})$, bovine serum albumin $(67 \mathrm{kDa})$, ovalbumin $(43 \mathrm{kDa})$, carbonic anhydrase $(30 \mathrm{kDa})$, soybean trypsin inhibitor $(20 \mathrm{kDa})$ and $\alpha$-lactalbumin $(14.4 \mathrm{kDa})$.

3.2. Biological Characteristics of HEA. The specificities of carbohydrate-binding of HEA were examined by hemagglutination-inhibition assay. The hemagglutinating activity of HEA (32 units) was totally inhibited by inulin at a concentration of $12.5 \mathrm{mM}$ (data not shown). Carbohydrate specificity was an important characteristic of lectins. It is interesting that only inulin, a plant polysaccharide, was able to inhibit the hemagglutinating activity of HEA. To date several inulin-specific lectins have been reported [14, 47, 48]. Hence HEA may be used in the production of immobilized lectin for affinity chromatography.

The hemagglutinating activity of HEA remained stable between $20^{\circ} \mathrm{C}$ and $70^{\circ} \mathrm{C}$. The activity was curtailed to half at $80^{\circ} \mathrm{C}$, and was completely abolished at $90^{\circ} \mathrm{C}$ (Table 3 ).
TABLE 4: Effects of $\mathrm{NaOH}$ and $\mathrm{HCl}$ solutions on hemagglutinating activity of HEA.

\begin{tabular}{lccc}
\hline pH value & $\begin{array}{c}\text { Hemagglutinating } \\
\text { activity } \\
\text { remaining (\%) }\end{array}$ & $\mathrm{pH}$ value & $\begin{array}{c}\text { Hemagglutinating } \\
\text { activity } \\
\text { remaining }(\%)\end{array}$ \\
\hline 0.7 & 0 & 11.8 & 100 \\
1.0 & 0 & 12.1 & 100 \\
1.3 & 0 & 12.4 & 25 \\
1.6 & 12.5 & 12.7 & 25 \\
1.9 & 100 & 13.0 & 12.5 \\
2.1 & 100 & 13.3 & 0 \\
\hline
\end{tabular}

Initial hemagglutinating activity of HEA solution was 32 hemagglutinating units.

Mushroom lectins differ from one another in thermostability. The lectin from G. capense was not attenuated following treatment at $100^{\circ} \mathrm{C}$ for 60 minutes [9], while the hemagglutinating activity of $P$. ostreatus lectin was reduced at and above $40^{\circ} \mathrm{C}$ [11]. However, the hemagglutinating activity of HEA was stable in the $\mathrm{pH}$ solutions range 1.9-12.1. When the $\mathrm{pH}$ value reached 1.3 or 13.3 , the hemagglutinating activity was completely eliminated (Table 4 ). HEA exhibited some similarity to the lectin from Armillaria luteo-virens in $\mathrm{pH}$ stability [14]. Compared with some lectins that are unstability to low, and high $\mathrm{pH}[13,44]$, HEA was much more robust in that it was not adversely affected by changes in the ambient $\mathrm{pH}$.

The majority of univalent, divalent and trivalent metallic chlorides including $\mathrm{K}^{+}, \mathrm{Fe}^{2+}, \mathrm{Mn}^{2+}, \mathrm{Zn}^{2+}, \mathrm{Pb}^{2+}, \mathrm{Co}^{2+}$, $\mathrm{Mg}^{2+}, \mathrm{Ca}^{2+}$ and $\mathrm{Al}^{3+}$ ions, did not affect the lectin activity. But the activity was inhibited by $\mathrm{Cu}^{2+}$ and $\mathrm{Hg}^{2+}$ ions at a concentration of $5 \mathrm{mM}$ and $10 \mathrm{mM}$, respectively. The hemagglutinating activity was completely suppressed by $\mathrm{Fe}^{3+}$ ions at a concentration of $12.5 \mathrm{mM}$ (Table 5). In the 
TABLE 5: Effects of cations on hemagglutinating activity of HEA.

\begin{tabular}{lccccc}
\hline & $1.25 \mathrm{mM}$ & $2.5 \mathrm{mM}$ & $5 \mathrm{mM}$ & $10 \mathrm{mM}$ & $20 \mathrm{mM}$ \\
\hline $\mathrm{K}^{+}$ & 32 & 32 & 32 & 32 & 32 \\
$\mathrm{Fe}^{2+}$ & 32 & 32 & 32 & 32 & 32 \\
$\mathrm{Zn}^{2+}$ & 32 & 32 & 32 & 32 & 32 \\
$\mathrm{Ca}^{2+}$ & 32 & 32 & 32 & 32 & 32 \\
$\mathrm{Mg}^{2+}$ & 32 & 32 & 32 & 32 & 32 \\
$\mathrm{Mn}^{2+}$ & 32 & 32 & 32 & 32 & 32 \\
$\mathrm{~Pb}^{2+}$ & 32 & 32 & 32 & 32 & 32 \\
$\mathrm{Al}^{3+}$ & 32 & 32 & 32 & 32 & 32 \\
$\mathrm{Co}^{2+}$ & 32 & 32 & 32 & 32 & 32 \\
$\mathrm{Cu}^{2+}$ & 32 & 32 & 0 & 0 & 0 \\
$\mathrm{Hg}^{2+}$ & 32 & 32 & 32 & 0 & 0 \\
$\mathrm{Fe}^{3+}$ & 32 & 0 & 0 & 0 & 0 \\
\hline
\end{tabular}

Initial hemagglutinating activity of HEA solution was 32 hemagglutinating units.

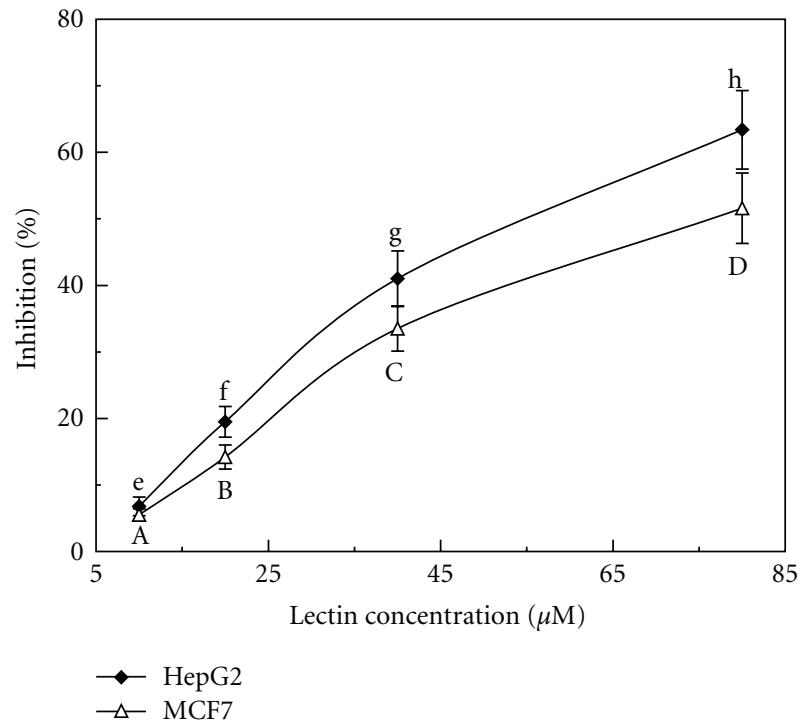

FIgURE 3: Inhibitory effect of HEA on proliferation of Hep G2 and MCF-7 cancer cells line in vitro. Results represent mean \pm $\mathrm{SD}(n=3)$. The $\mathrm{IC}_{50}$ values toward HepG2 cells and MCF7 cells are $56.1 \mu \mathrm{M}$ and $76.5 \mu \mathrm{M}$, respectively. Different alphabets next to the data points indicate statistically significant difference $(P<.05)$ when the data are analyzed by analysis of variance followed by Duncan's multiple range test.

present study, $\mathrm{Cu}^{2+}, \mathrm{Fe}^{3+}$, and $\mathrm{Hg}^{2+}$ ions when presented at $5 \mathrm{mM}, 2.5 \mathrm{mM}$, and $10 \mathrm{mM}$, respectively, diminished the hemagglutinating activity of HEA. In contrast, $\mathrm{Ca}^{2+}, \mathrm{Mg}^{2+}$, $\mathrm{Mn}^{2+}, \mathrm{Zn}^{2+}, \mathrm{AL}^{3+}, \mathrm{Pb}^{2+}, \mathrm{K}^{+}, \mathrm{Co}^{2+}$, and $\mathrm{Fe}^{2+}$ ions were devoid of any effect. It is known that different mushroom lectins might be affected differently by the ions. $\mathrm{Al}^{3+}$ ions strongly potentiated the hemagglutinating activity of $P$. ostreatus and $P$. citrinopileatus lectin $[11,44]$, but did not influence the lectin from S. commune [13]. $\mathrm{Ca}^{2+}, \mathrm{Mg}^{2+}, \mathrm{Mn}^{2+}$, and $\mathrm{Zn}^{2+}$ ions did not alter the hemagglutinating activity of lectins isolated from Amanita pantherina [49], G. frondosa [18], and H. erinaceum [17], but inhibited S. commune lectin [13].

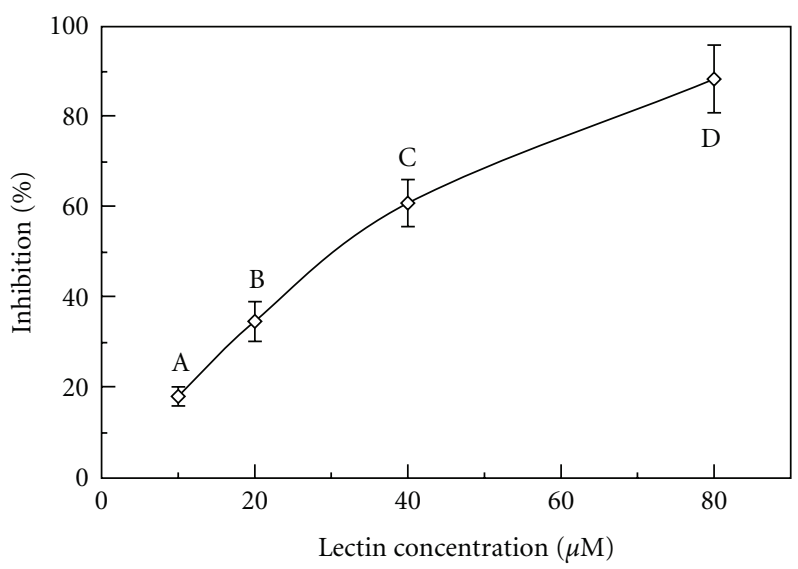

FIgURE 4: Inhibitory effect of HEA on activity of HIV-1 reverse transcriptase. Results represent mean $\pm \mathrm{SD}(n=3)$. The $\mathrm{IC}_{50}$ value is $31.7 \mu \mathrm{M}$. Different alphabets next to the data points indicate statistically significant difference $(P<.05)$ when the data are analyzed by analysis of variance followed by Duncan's multiple range test.

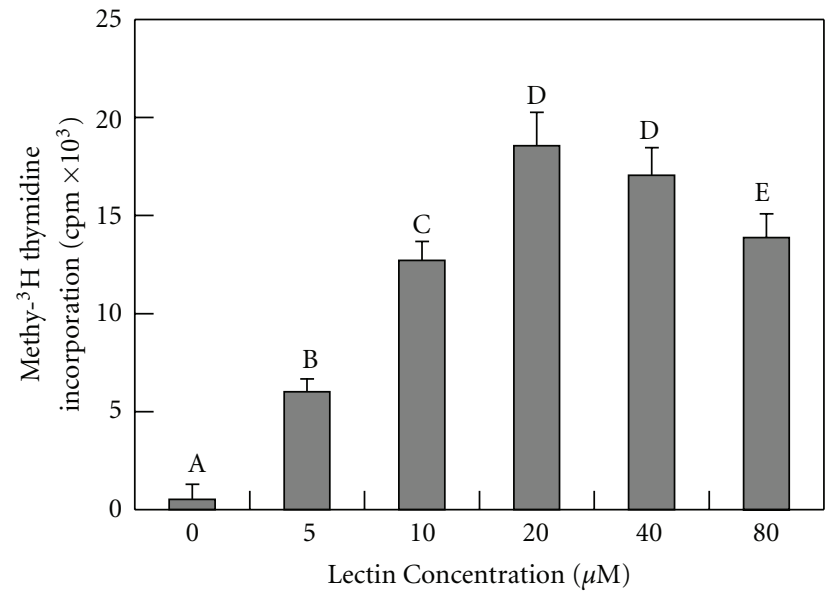

FIGURE 5: Mitogenic response of murine splenocytes to the lectin isolated from $H$. erinaceum as reflected by uptake of [methyl- ${ }^{3} \mathrm{H}$ ] thymidine uptake in vitro. Results represent means $\pm \mathrm{SD}(n=3)$. Maximal stimulation of thymidine uptake was brought about by a lectin concentration of $20 \mu \mathrm{M}$. There was an approximately 36-fold increase over the control value without lectin. Different alphabets next to the data points indicate statistically significant difference $(P<.05)$ when the data are analyzed by analysis of variance followed by Duncan's multiple range test.

3.3. Other Biological Activities of HEA. Lectins from A. bisporus, $P$. ostreatus, T. mongolicum, and $V$. volvacea exhibit antitumor activity in vivo or antiproliferative activity in vitro $[5,11,23]$. A. luteo-virens was devoid of antiproliferative activity on HepG2 cells [14]. HEA inhibited the proliferation of HepG2 and MCF7 tumor cells with an $\mathrm{IC}_{50}$ value of $56.1 \mu \mathrm{M}$ and $76.5 \mu \mathrm{M}$, respectively (Figure 3 ). The potent antiproliferative activity of HEA is remarkable and hopefully it can be developed into an aided agent for cancer therapy.

To date very few lectins have been reported with antifungal activity and the number of lectins claimed to 
TABLE 6: Comparison of characteristics of HEL [17] and HEA (this study).

\begin{tabular}{|c|c|c|}
\hline Characteristics & HEL & HEA \\
\hline \multicolumn{3}{|l|}{ Chromatographic behavior on } \\
\hline DEAE ion exchanger & not determined & adsorbed, eluted with $300 \mathrm{mM} \mathrm{NaCl}$ \\
\hline DEAE-Toyopearl column & $\begin{array}{l}\text { adosorbed, eluted with } 200 \mathrm{mM} \mathrm{NaCl} \text { in } \\
\text { Tris buffer. }\end{array}$ & not determined \\
\hline $\mathrm{CM}$ ion exchanger & not determined & adsorbed, eluted with $50 \mathrm{Mm} \mathrm{NaCl}$ \\
\hline Mono-S column & Absorbed & not determined \\
\hline Moleculr Mass (kDa) & 54 & 51 \\
\hline Subunit molecular mass $(\mathrm{kDa})$ & 15 and 16 & 51 \\
\hline N-terminal sequence & not determined & AFGQLSFANLAAADF \\
\hline Thermostability & $\mathrm{Up}$ to $70^{\circ} \mathrm{C}$ & up to $70^{\circ} \mathrm{C}$ \\
\hline pH stability & $5.0-10.5$ & $1.9-12.1$ \\
\hline \multicolumn{3}{|l|}{ Sugar specificity } \\
\hline (i) mono- or oligo-saccharides & $\begin{array}{l}\text { NeuGc, NeuAc, } \\
3^{\prime} \text {-N-Acetylneuramin-lactose and } \\
\text { galacturonic acid }\end{array}$ & inulin and not by simple sugars \\
\hline (ii) glycoproteins & asialo-BSM, Asialofetuin & not determined \\
\hline Sialic acid-binding activating & Yes & not determined \\
\hline Effect of cations on hemagglutinating activity & no effect & $\begin{array}{l}\text { activity inhibited by } \mathrm{Cu}^{2+}, \mathrm{Fe}^{3+} \text {, and } \mathrm{Hg}^{2+} \\
\text { ions }\end{array}$ \\
\hline Antifungal activity & not determined & no effect \\
\hline Antiproliferative activity & not determined & $\begin{array}{l}\mathrm{IC}_{50} \text { of } 56.1 \mu \mathrm{M} \text { toward HepG2 cells, and } \\
76.5 \mu \mathrm{M} \text { toward MCF7 cells, respectively }\end{array}$ \\
\hline Mitogenic activity toward splenocytes & not determined & 35.8 fold increase over basal value \\
\hline HIV-1 reverse transcriptase inhibitory activity & not determined & $\mathrm{IC}_{50}=31.7 \mu \mathrm{M}$ \\
\hline
\end{tabular}

have antifungal activity is also relatively small [50-53]. The lectin lacked antifungal and ribonuclease activities (data not shown). HIV-RT is a key enzyme of the HIV life cycle. Screening of HIV-RT inhibitors is currently a strategy to search for anti-HIV drugs. It is possible that the mechanism of inhibition is analogous to the protein-protein interaction involved in the inhibition of HIV-1 reverse transcriptase by the homologous protease [54]. It is worth mentioning that HEA manifested a weak potent inhibitory activity toward HIV-1 RT ( $\mathrm{IC}_{50}=31.7 \mu \mathrm{M}$, Figure 4$)$, compared with other lectins such as $S$. commune lectin $\left(\mathrm{IC}_{50}=1.2 \mu \mathrm{M}\right)$, $P$. citrinopileatus lectin $\left(\mathrm{IC}_{50}=0.93 \mu \mathrm{M}\right)$ and $P$. adiposa lectin $\left(\mathrm{IC}_{50}=1.9 \mu \mathrm{M}\right)$, respectively $[13,44,48]$. However, The $P$. ostreatus lectin and $G$. capense lectin lacked any inhibitory effect on HIV-1 reverse transcriptase $[9,11]$. It manifested potent mitogenic activity toward murine spleen cells, producing a 35.8-fold stimulation over the control value at at a dose of $20 \mu \mathrm{M}$ (Figure 5). The mitogenic activity of HEA toward murine splenocytes is in accordance with reports on lectins from the mushrooms Volvariella volvacea $[8,55]$ and Agrocybe cylindracea [9].

3.4. Comparison with HEA and HEL. A comparison with HEL [17] and HEA (this study) is listed in Table 6. Nterminal sequence and many biological activities, including antifungal activity, antiproliferative activity, mitogenic activity and HIV-1 RT inhibitory activity have been determined in
HEA. The N-terminal sequence, antifungal activity, antiproliferative activity and HIV-1 RT inhibitory activity of HEL has not been demonstrated. However, the molecular mass of HEL is different from HEA. HEL has a molecular mass in the vicinity of $54 \mathrm{kDa}$ and composed of two different subunits with a molecular mass of 15 and $16 \mathrm{kDa}$, while HEA in this study was monomeric and had a molecular mass about $51 \mathrm{kDa}$. The two lectins have very similar the thermostability. The $\mathrm{pH}$ stability of HEA ( $\mathrm{pH}$ 1.9-12.1) is much higher than that of HEL ( $\mathrm{pH}$ 5.0-10.5). The hemagglutinating activity of the HEA but not that of HEL was inhibited by $\mathrm{Cu}^{2+}$, $\mathrm{Fe}^{3+}$, and $\mathrm{Hg}^{2+}$ ion. HEA and HEL had distinctive sugar specificities. HEL could interact with $\mathrm{N}$-glycolylneuramic acid, N-acetylneuramic acid, 3'-N-acetylneuramin-lactose and galacturonic acid, while HEA was only influenced by inulin.

\section{Conclusions}

In summary, a novel lectin named HEA was isolated from dried fruiting bodies of the mushroom. It possessed a distinctive N-terminal sequence, carbohydrate specificity, and potent antiproliferative activity toward tumor cell lines, potent mitogen activity toward splenocytes and HIV-1 RT inhibitory activity. It represents an addition to the existing list of mushroom lectins. 


\section{Acknowledgments}

This work was financially supported by National Grants of China (2007BAD89B00 and 2010CB732202).

\section{References}

[1] T. B. Ng, "Peptides and proteins from fungi," Peptides, vol. 25, no. 6, pp. 1055-1073, 2004.

[2] S. Oguri, M. Kamoshida, Y. Nagata, Y. S. Momonoki, and H. Kamimura, "Characterization and sequence of tomato $2 S$ seed albumin: a storage protein with sequence similarities to the fruit lectin," Planta, vol. 216, no. 6, pp. 976-984, 2003.

[3] W. J. Peumans, W. Zhang, A. Barre, C. Houlès Astoul, P. J. Balint-Kurti, P. Rovira, P. Rougé, G. D. May, F. Van Leuven, P. Truffa-Bachi, and E. J. M. Van Damme, "Fruit-specific lectins from banana and plantain," Planta, vol. 211, no. 4, pp. 546554, 2000.

[4] W. J. Peumans and E. J. Van Damme, "Lectins as plant defense proteins," Plant Physiology, vol. 109, no. 2, pp. 347-352, 1995.

[5] H. Wang, T. B. Ng, and V. E. C. Ooi, "Lectins from mushrooms," Mycological Research, vol. 102, no. 8, pp. 897906, 1998.

[6] R. Loris, T. Hamelryck, J. Bouckaert, and L. Wyns, "Legume lectin structure," Biochimica et Biophysica Acta, vol. 1383, no. 1, pp. 9-36, 1998.

[7] A. M. Wu, J. H. Wu, M.-S. Tsai, G. V. Hegde, S. R. Inamdar, B. M. Swamy, and A. Herp, "Carbohydrate specificity of a lectin isolated from the fungus Sclerotium rolfsii," Life Sciences, vol. 69, no. 17, pp. 2039-2050, 2001.

[8] Q.-B. She, T.-B. Ng, and W.-K. Liu, "A novel lectin with potent immunomodulatory activity isolated from both fruiting bodies and cultured mycelia of the edible mushroom Volvariella volvacea," Biochemical and Biophysical Research Communications, vol. 247, no. 1, pp. 106-111, 1998.

[9] P. H. K. Ngai and T. B. Ng, "A mushroom (Ganoderma capense) lectin with spectacular thermostability, potent mitogenic activity on splenocytes, and antiproliferative activity toward tumor cells," Biochemical and Biophysical Research Communications, vol. 314, no. 4, pp. 988-993, 2004.

[10] H. Wang, T. B. Ng, and Q. Liu, "Isolation of a new heterodimeric lectin with mitogenic activity from fruiting bodies of the mushroom Agrocybe cylindracea," Life Sciences, vol. 70 , no. 8 , pp. $877-885,2002$.

[11] H. Wang, J. Gao, and T. B. Ng, "A new lectin with highly potent antihepatoma and antisarcoma activities from the oyster mushroom Pleurotus ostreatus," Biochemical and Biophysical Research Communications, vol. 275, no. 3, pp. 810-816, 2000.

[12] H. X. Wang, T. B. Ng, W. K. Liu, V. E. C. Ooi, and S. T. Chang, "Isolation and characterization of two distinct lectins with antiproliferative activity from the cultured mycelium of the edible mushroom Tricholoma mongolicum," International Journal of Peptide and Protein Research, vol. 46, no. 6, pp. 508513, 1995.

[13] C. H. Han, Q. H. Liu, T. B. Ng, and H. X. Wang, "A novel homodimeric lactose-binding lectin from the edible split gill medicinal mushroom Schizophyllum commune," Biochemical and Biophysical Research Communications, vol. 336, no. 1, pp. 252-257, 2005.

[14] K. Feng, Q. H. Liu, T. B. Ng, H. Z. Liu, J. Q. Li, G. Chen, H. Y. Sheng, Z. L. Xie, and H. X. Wang, "Isolation and characterization of a novel lectin from the mushroom Armillaria luteo-virens," Biochemical and Biophysical Research Communications, vol. 345, no. 4, pp. 1573-1578, 2006.

[15] H. Kawagishi, Y. Abe, T. Nagata, A. Kimura, and S. Chiba, "A lectin from the mushroom Pholiota aurivella," Agricultural and Biological Chemistry, vol. 55, no. 10, pp. 2485-2489, 1991.

[16] H. Kawagishi, S.-I. Mitsunaga, M. Yamawaki, M. Ido, A. Shimada, T. Kinoshita, T. Murata, T. Usui, A. Kimura, and S. Chiba, "Alectin from mycelia of the fungus Ganoderma lucidum," Phytochemistry, vol. 44, no. 1, pp. 7-10, 1997.

[17] H. Kawagishi, H. Mori, A. Uno, A. Kimura, and S. Chiba, "A sialic acid-binding lectin from the mushroom Hericium erinaceum," FEBS Letters, vol. 340, no. 1-2, pp. 56-58, 1994.

[18] H. Kawagishi, A. Nomura, T. Mizuno, A. Kimura, and S. Chiba, "Isolation and characterization of a lectin from Grifola frondosa fruiting bodies," Biochimica et Biophysica Acta, vol. 1034, no. 3, pp. 247-252, 1990.

[19] H. Kawagishi, A. Nomura, T. Yumen, T. Mizuno, T. Hagiwara, and T. Nakamura, "Isolation and properties of a lectin from the fruiting bodies of Agaricus blazei," Carbohydrate Research, vol. 183, no. 1, pp. 150-154, 1988.

[20] H. Kawagishi, H. Suzuki, H. Watanabe, H. Nakamura, T. Sekiguchi, T. Murata, T. Usui, K. Sugiyama, H. Suganuma, T. Inakuma, K. Ito, Y. Hashimoto, M. Ohnishi-Kameyama, and T. Nagata, "A lectin from an edible mushroom Pleurotus ostreatus as a food intake-suppressing substance," Biochimica et Biophysica Acta, vol. 1474, no. 3, pp. 299-308, 2000.

[21] H. Kawagishi, J.-I. Takagi, T. Taira, T. Murata, and T. Usui, "Purification and characterization of a lectin from the mushroom Mycoleptodonoides aitchisonii," Phytochemistry, vol. 56, no. 1 , pp. 53-58, 2001.

[22] H. X. Wang and T. B. Ng, "Examination of lectins, polysaccharopeptide, polysaccharide, alkaloid, coumarin and trypsin inhibitors for inhibitory activity against human immunodeficiency virus reverse transcriptase and glycohydrolases," Planta Medica, vol. 67, no. 7, pp. 669-672, 2001.

[23] H. X. Wang, T. B. Ng, W. K. Liu, V. E. C. Ooi, and S. T. Chang, "Polysaccharide-peptide complexes from the cultured mycelia of the mushroom Coriolus versicolor and their culture medium activate mouse lymphocytes and macrophages," International Journal of Biochemistry and Cell Biology, vol. 28, no. 5, pp. 601607, 1996.

[24] B.-K. Yang, J.-B. Park, and C.-H. Song, "Hypolipidemic effect of an exo-biopolymer produced from a submerged mycelial culture of Hericium erinaceus," Bioscience, Biotechnology and Biochemistry, vol. 67, no. 6, pp. 1292-1298, 2003.

[25] D. M. Kim, C. W. Pyun, H. G. Ko, et al., "Isolation of antimicrobial substances from Hericium erinaceum," Mycobiology, vol. 28, pp. 33-38, 2000.

[26] T. Mizuno, H. Saito, T. Nishitoba, et al., "Antitumor-active substances from mushrooms," Food Review International, vol. 11, pp. 23-61, 1995.

[27] S. Kuwahara, E. Morihiro, A. Nemoto, et al., "Synthesis and absolute configuration of a cytotoxic fatty acid isolated from the mushroom Hericium erinaceum," Bioscience, Biotechnology, and Biochemistry, vol. 56, pp. 1417-1419, 1992.

[28] C.-P. Liu, J.-N. Fang, X.-Y. Li, and X.-Q. Xiao, "Structural characterization and biological activities of SC4, an acidic polysaccharide from Salvia chinensis," Acta Pharmacologica Sinica, vol. 23, no. 2, pp. 162-166, 2002.

[29] J.-L. Mau, H.-C. Lin, and C.-C. Chen, "Antioxidant properties of several medicinal mushrooms," Journal of Agricultural and Food Chemistry, vol. 50, no. 21, pp. 6072-6077, 2002. 
[30] E. W. Lee, K. Shizuki, S. Hosokawa, M. Suzuki, H. Suganuma, T. Inakuma, J. Li, M. Ohnishi-Kameyama, T. Nagata, S. Furukawa, and H. Kawagishi, "Two novel diterpenoids, erinacines $\mathrm{H}$ and I from the mycelia of Hericium erinaceum," Bioscience, Biotechnology and Biochemistry, vol. 64, no. 11, pp. 2402-2405, 2000.

[31] H. Kawagishi, A. Shimada, R. Shirai, K. Okamoto, F. Ojima, H. Sakamoto, Y. Ishiguro, and S. Furukawa, "Erinacines A, B and $\mathrm{C}$, strong stimulators of nerve growth factor (NGF)-synthesis, from the mycelia of Hericium erinaceum," Tetrahedron Letters, vol. 35, no. 10, pp. 1569-1572, 1994.

[32] H. Kawagishi, M. Ando, K. Shinba, H. Sakamoto, S. Yoshida, F. Ojima, Y. Ishiguro, N. Ukai, and S. Furukawa, "Chromans, hericenones F, G and $\mathrm{H}$ from the mushroom Hericium erinaceum," Phytochemistry, vol. 32, no. 1, pp. 175-178, 1992.

[33] H. Kawagishi, M. Ando, H. Sakamoto, S. Yoshida, F. Ojima, Y. Ishiguro, N. Ukai, and S. Furukawa, "Hericenones C, D and E, stimulators of nerve growth factor (NGF)-synthesis, from the mushroom Hericium erinaceum," Tetrahedron Letters, vol. 32, no. 35, pp. 4561-4564, 1991.

[34] T. Mizuno, T. Wasa, H. Ito, C. Suzuki, and N. Ukai, "Antitumor-active polysaccharides isolated from the fruiting body of Hericium erinaceum, an edible and medicinal mushroom called yamabushitake or houtou," Bioscience, Biotechnology, and Biochemistry, vol. 56, no. 2, pp. 347-348, 1992.

[35] H. X. Wang and T. B. Ng, "A new laccase from dried fruiting bodies of the monkey head mushroom Hericium erinaceum," Biochemical and Biophysical Research Communications, vol. 322, no. 1, pp. 17-21, 2004.

[36] L. Lu, J. Li, and Y. Cang, "PCR-based sensitive detection of medicinal fungi hericium species from ribosomal internal transcribed spacer (ITS) sequences," Biological and Pharmaceutical Bulletin, vol. 25, no. 8, pp. 975-980, 2002.

[37] U. K. Laemmli and M. Favre, "Gel electrophoresis of proteins," Journal of Molecular Biology, vol. 80, pp. 575-599, 1973.

[38] F. Martin, A. Aerts, D. Ahrén, A. Brun, E. G. J. Danchin, F. Duchaussoy, J. Gibon, A. Kohler, E. Lindquist, V. Pereda, A. Salamov, H. J. Shapiro, J. Wuyts, D. Blaudez, M. Buée, P. Brokstein, B. Canbäck, D. Cohen, P. E. Courty, P. M. Coutinho, C. Delaruelle, J. C. Detter, A. Deveau, S. DiFazio, S. Duplessis, L. Fraissinet-Tachet, E. Lucic, P. Frey-Klett, C. Fourrey, I. Feussner, G. Gay, J. Grimwood, P. J. Hoegger, P. Jain, S. Kilaru, J. Labbé, Y. C. Lin, V. Legué, F. Le Tacon, R. Marmeisse, D. Melayah, B. Montanini, M. Muratet, U. Nehls, H. Niculita-Hirzel, M. P. O.-L. Secq, M. Peter, H. Quesneville, B. Rajashekar, M. Reich, N. Rouhier, J. Schmutz, T. Yin, M. Chalot, B. Henrissat, U. Kües, S. Lucas, Y. Van De Peer, G. K. Podila, A. Polle, P. J. Pukkila, P. M. Richardson, P. Rouzé, I. R. Sanders, J. E. Stajich, A. Tunlid, G. Tuskan, and I. V. Grigoriev, "The genome of Laccaria bicolor provides insights into mycorrhizal symbiosis," Nature, vol. 452, no. 7183, pp. 88-92, 2008.

[39] M. A. Wälti, P. J. Walser, S. Thore, A. Grünler, M. Bednar, M. Künzler, and M. Aebi, "Structural basis for chitotetraose coordination by CGL3, a novel galectin-related protein from Coprinopsis cinerea," Journal of Molecular Biology, vol. 379, no. 1, pp. 146-159, 2008.

[40] S. Oguri, A. Ando, and Y. Nagata, "A novel developmental stage-specific lectin of the basidiomycete Pleurotus cornucopiae," Journal of Bacteriology, vol. 178, no. 19, pp. 5692-5698, 1996.

[41] R. W. Crenshaw, S. N. Harper, M. Moyer, and L. S. Privalle, "Isolation and characterization of a cDNA clone encoding a lectin gene from Agaricus bisporus," Plant Physiology, vol. 107, no. 4, pp. 1465-1466, 1995.

[42] C. Zhao, H. Sun, X. Tong, and Y. Qi, "An antitumour lectin from the edible mushroom Agrocybe aegerita," Biochemical Journal, vol. 374, no. 2, pp. 321-327, 2003.

[43] J.-L. Ko, C.-I. Hsu, R.-H. Lin, C.-L. Kao, and J.-Y. Lin, "A new fungal immunomodulatory protein, FIP-fve isolated from the edible mushroom, Flammulina velutipes and its complete amino acid sequence," European Journal of Biochemistry, vol. 228, no. 2, pp. 244-249, 1995.

[44] Y. R. Li, Q. H. Liu, H. X. Wang, and T. B. Ng, "A novel lectin with potent antitumor, mitogenic and HIV-1 reverse transcriptase inhibitory activities from the edible mushroom Pleurotus citrinopileatus," Biochimica et Biophysica Acta, vol. 1780, no. 1, pp. 51-57, 2008.

[45] H. X. Wang and T. B. Ng, "Purification of a novel lowmolecular-mass laccase with $\mathrm{HIV}-1$ reverse transcriptase inhibitory activity from the mushroom Tricholoma giganteum," Biochemical and Biophysical Research Communications, vol. 315, no. 2, pp. 450-454, 2004.

[46] H. X. Wang and T. B. Ng, "An antifungal peptide from baby lima bean," Applied Microbiology and Biotechnology, vol. 73, no. 3, pp. 576-581, 2006.

[47] Q. Liu, H. Wang, and T. B. Ng, "Isolation and characterization of a novel lectin from the wild mushroom Xerocomus spadiceus," Peptides, vol. 25, no. 1, pp. 7-10, 2004.

[48] G. Q. Zhang, J. Sun, H. X. Wang, and T. B. Ng, "A novel lectin with antiproliferative activity from the medicinal mushroom Pholiota adiposa," Acta biochimica Polonica, vol. 56, no. 3, pp. 415-421, 2009.

[49] C. Zhuang, T. Murata, T. Usui, H. Kawagishi, and K. Kobayashi, "Purification and characterization of a lectin from the toxic mushroom Amanita pantherina," Biochimica et Biophysica Acta, vol. 1291, no. 1, pp. 40-44, 1996.

[50] X. Y. Ye, T. B. Ng, P. W. K. Tsang, and J. Wang, "Isolation of a homodimeric lectin with antifungal and antiviral activities from red kidney bean (Phaseolus vulgaris) seeds," Journal of Protein Chemistry, vol. 20, no. 5, pp. 367-375, 2001.

[51] O. Gozia, J. Ciopraga, T. Bentia, M. Lungu, I. Zamfirescu, R. Tudor, A. Roseanu, and F. Nitu, "Antifungal properties of lectin and new chitinases from potato tubers," Comptes Rendus de l'Academie des Sciences. Series III, vol. 316, no. 8, pp. 788792, 1993.

[52] W. F. Broekaert, J. A. N. Van Parijs, F. Leyns, H. Joos, and W. J. Peumans, "A chitin-binding lectin from stinging nettle rhizomes with antifungal properties," Science, vol. 245, no. 4922, pp. 1100-1102, 1989.

[53] J. Ciopraga, O. Gozia, R. Tudor, L. Brezuica, and R. J. Doyle, "Fusarium sp. growth inhibition by wheat germ agglutinin," Biochimica et Biophysica Acta, vol. 1428, no. 2-3, pp. 424-432, 1999.

[54] M. Böttcher and F. Grosse, "HIV-1 protease inhibits its homologous reverse transcriptase by protein-protein interaction," Nucleic Acids Research, vol. 25, no. 9, pp. 1709-1714, 1997.

[55] H.-C. Hsu, C.-I. Hsu, R.-H. Lin, C.-L. Kao, and J.-Y. Lin, "Fipvvo, a new fungal immunomodulatory protein isolated from Volvariella volvacea," Biochemical Journal, vol. 323, part 2, pp. 557-565, 1997. 

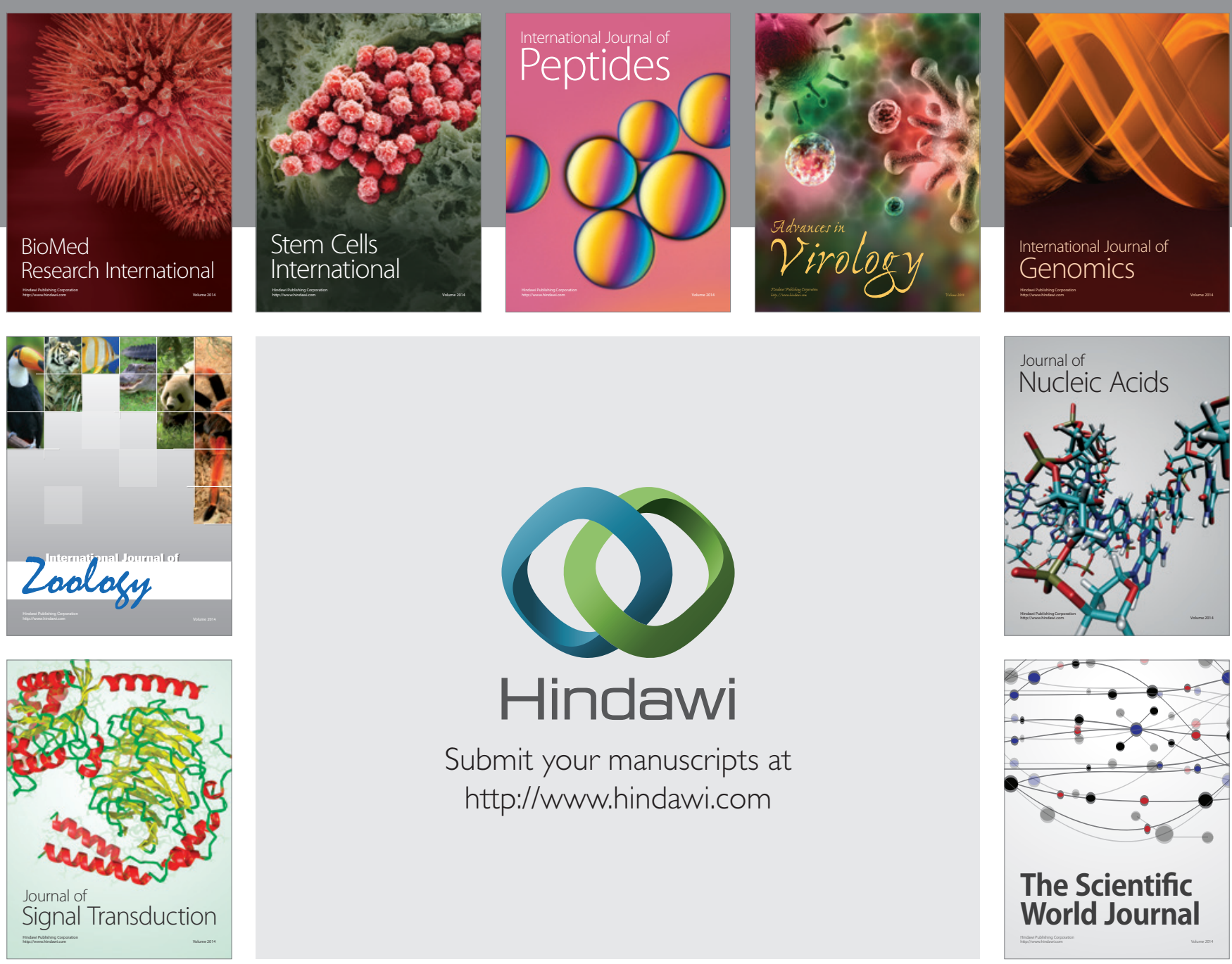

Submit your manuscripts at

http://www.hindawi.com
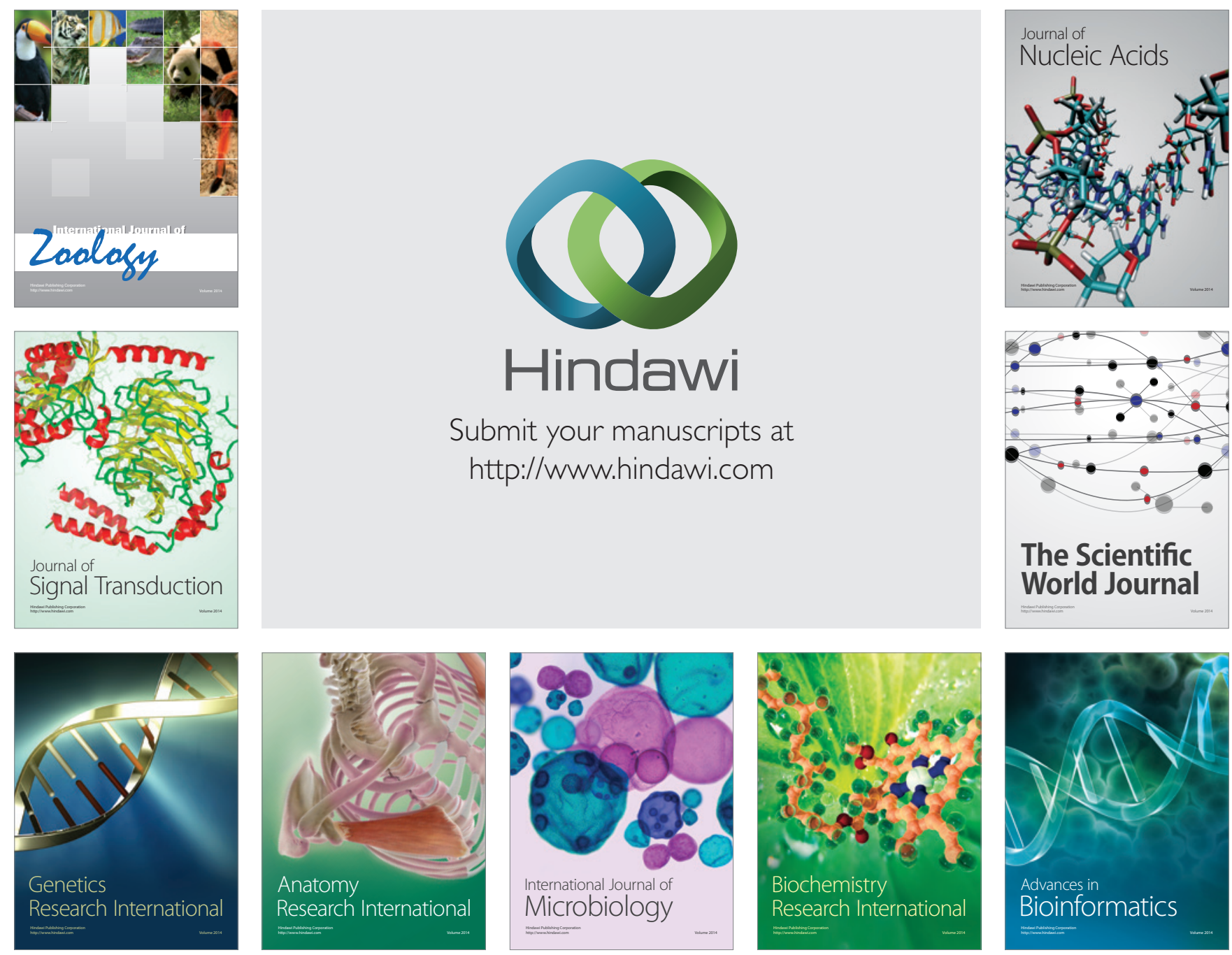

The Scientific World Journal
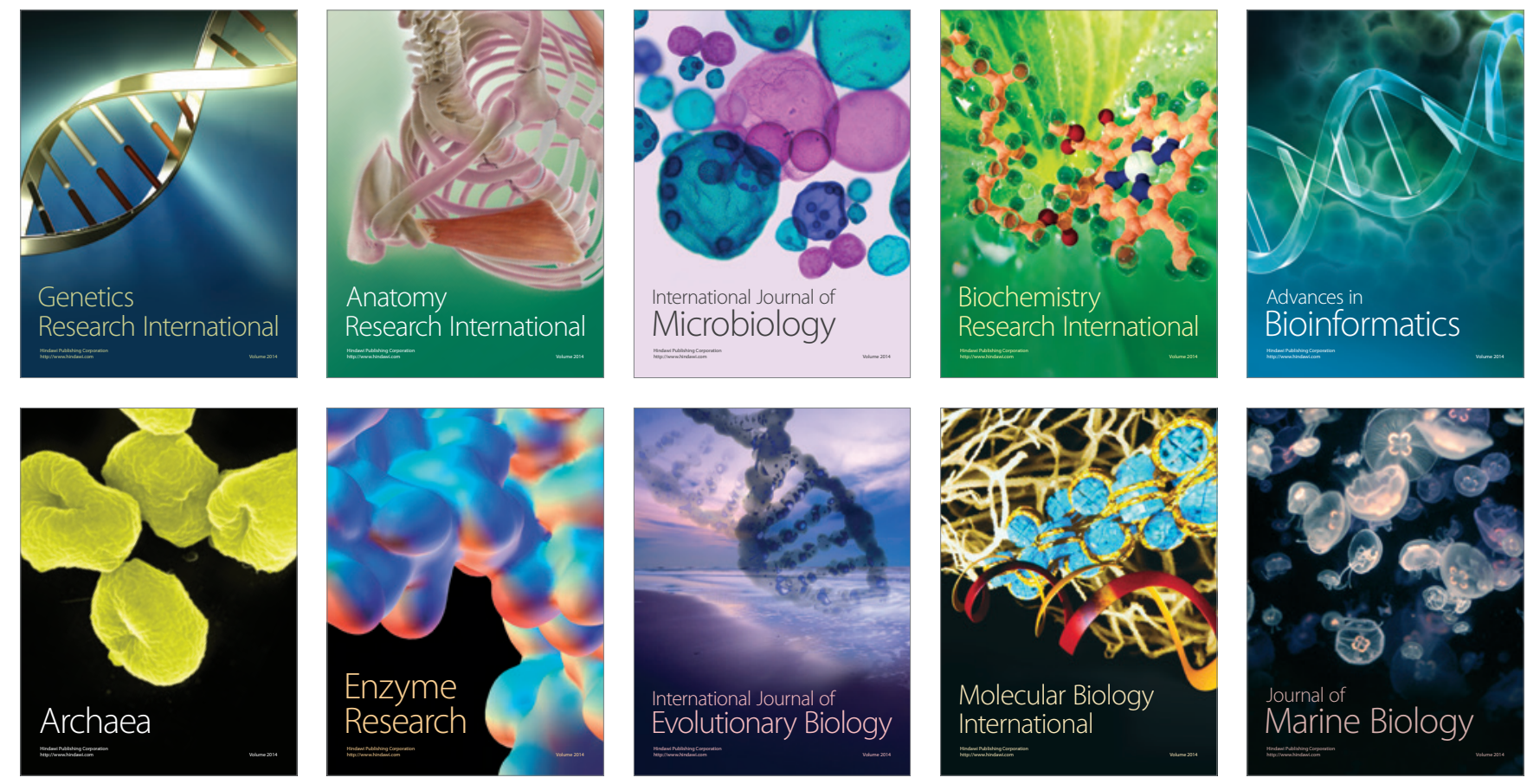